Edukids volume 16 (2) tahun 2019

EDUKIDS: Jurnal Pertumbuhan, Perkembangan, dan Pendidikan Anak Usia Dini

Jln. Dr. Setiabudhi No. 229 Kota Bandung 40154. e-mail: edukid@upi.edu website: http://ejournal.upi.edu/index.php/edukid

\title{
KEMANDIRIAN ANAK USIA DINI MENURUT PANDANGAN GURU DAN ORANG TUA
}

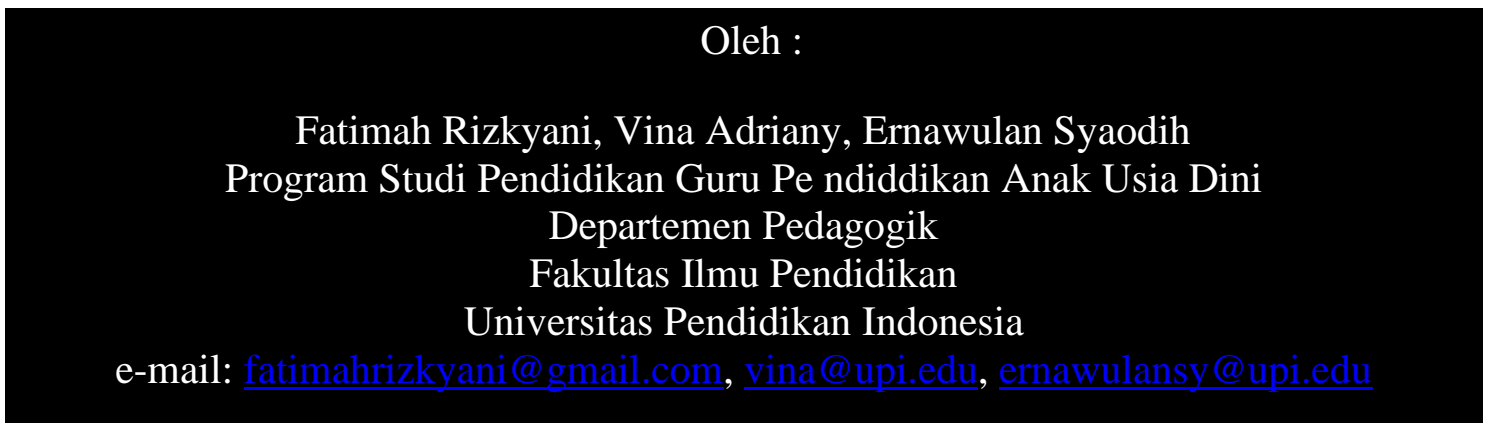

Abstrak: Pembentukan kemandirin pada usia dini sangatlah penting dipahami oleh guru dan orang tua. Sebab orang tua dan gurulah yang sangat berperan dalam pembentukan kemandirian anak.. Penelitian ini bertujuan untuk mengetahui faktor dan tindakan apa sajakah yang diberikan dan terjadi pada anak yang dapat membentuk kemandirian anak, bagaimana kemandirian anak usia dini, dan hambatan apa sajakah yang dapat menghambat kemandirian anak usia dini. Subjek pada penelitian ini berjumlah enam partisipan yang terdiri dari tiga orang guru dan tiga orang tua. Metode penelitian yang digunakan yaitu penelitian studi kasus dengan teknik analisis data menggunakan grounded theory. Hasil dari penelitian ini menjelaskan bagaiamana guru dan orang tua memiliki pandangan bahwa kemandirian anak itu penting dikembangkan karena dengan itu anak dapat melakukan segala sesuatunya sendiri dan tidak tergantung pada orang lain serta guru dan orang tua berpandangan kemandirian anak dipengaruhi oleh beberapa faktor yaitu faktor pendorong meliputi adik, kekompakan orang tua, konsistensi dan teman akan membentuk kemandirian anak, sedangkan nenek yang telalu memanjakan cucunya, lingkungan keluarga yang tidak mandiri serta telepon genggam merupakan faktor yang dapat menghambat kemandirian anak. Rekomendasi ditujukan kepada guru dan orang tua agar dapat bekerjasama dalam membentuk kemandirian anak dengan memberikan banyak kegiatan yang positif agar anak dapat terbentuk kemandiriannya.

\section{Kata kunci: kemandirian, orang tua dan guru}

Abstract: The formation of infertility at an early age is very important to be understood by teachers and parents. Because parents and teachers are very instrumental in shaping the independence of children. This study aims to find out what factors and actions are given and occur in children who can shape the independence of children, how independence of early childhood, and what obstacles can inhibit independence. early childhood. The subjects in this study were six participants consisting of three teachers and three parents. The research method used is case study research with data analysis techniques using grounded theory. The results of this study explain how teachers and parents have the view that children's independence is important to be developed because with it children can do everything themselves and not depend on others and teachers and parents view the child's independence is influenced by several factors, namely the driving factors include younger sibling, the cohesiveness of parents, consistency and friends will shape the independence of children, while grandmothers who are too pampering their grandchildren, family environment that is not independent and cell phones are factors 

that can inhibit children's independence. Recommendations are addressed to teachers and parents so they can work together in shaping the independence of children by providing many positive activities so that children can form their independence.

\section{Keywords: Independence, Parents and Teachers}

\section{PENDAHULUAN}

Generasi muda atau yang diawali dari masa usia dini menjadi hal yang perlu diperhatikan karena menjadi dasar terbangunnya sebuah generasi. Pada usia dini, anak akan melalui tahap perkembangan psikososial yang dikemukakan oleh Erikson yaitu autonomy versus shame and doubt, dimana pada tahap ini anak harus diberi kepercayaan agar dapatmengembangkan kemandiriannya. Sejalan dengan upaya pemerintah untuk mengatasi permasalahan kemandirian adalah dengan menjadikan kemandirian salah satu karakter yang harus dibentuk dalam tujuan pendidikan, tertuang pada Undang-undang Sisdiknas pasal 3 tahun 2003, tujuan pendidikan di Indonesia adalah berkembangnya potensi peserta didik agar menjadi manusia yang beriman dan bertakwa kepada Tuhan Yang Maha Esa, berakhlak mulia, sehat, berilmu, cakap, kreatif, mandiri, dan menjadi warga untuk membentuk watak serta peradaban bangsa yang bermartabat (Desmita, 2011).

Untuk itu kemandirian sangat diperlukan dalam menentukan arah pilihan individu. Memupuk kemandirian sejak usia dini sangat diperlukan.Sejalan dengan pendapat Yamin (2013) kemandirian merupakan karakter utama dalam kehidupan mulai sejak usia dini, membentuk anak usia dini memerlukan proses yang bertahap dan sesuai dengan tingkat perkembangannya. Kemandirian akan mendukung anak dalam belajar memahami pilihan perilaku beserta resiko yang harus dipertanggungjawabkan oleh anak. Semakin dikekang, anak akan semakin sulit untuk mengendalikan emosi, dengan kemungkinan perilaku yang akan muncul adalah perilaku memberontak atau justru, sangat tergantung pada orang lain. Sejalan dengan pendapat Anisah (2017) bahwa “ Kemandiriana akan membawa pengaruh yang besar bagi pengalaman kehidupan selanjutnya, karena dalam kehidupan sehari-hari anak diharapkan mampu melaksanakan tugas sendiri sampai selesai, bertanggungjawab akan tugasnya, semangat dalam bekerja serta menghargai dan memelihara hasil karyanya sendiri".

Pendidikan Anak Usia Dini (PAUD) adalah jenjang pendidikan sebelum jenjang pendidikan dasar yang merupakan suatu upaya pembinaan yang ditujukan bagi anak, dalam UndangUndang No. 20 Tahun 2003 pasal 28 ayat 1 menyatakan bahwa rentang anak usia dini adalah 0-6 tahun. Sementara menurut kajian rumpun keilmuan PAUD dan penyelenggaraannya di beberapa negara, PAUD dilaksanakan sejak usia 0-8 tahun, pada jenjang inilah semua aspek pendukung disekeliling anak perlu diperhatikan. Orang tua dan guru merupakan salah satu pembina dan pemerhati bagi anak, yang dapat menstimulus dan menyaksikan perkembangan karakter anak salah satunya adalah kemadirian anak, karena orang tua dan guru merupakan orang dewasa yang berada dilingkungan perkembangan anak. Sejalan dengan pendapat Susanto (2017) orang tua mempunyai peranan penting karena mereka merupakan pembimbing dan fasilitator pertama yang akan menjadi teladan anak dan guru berperan pada sebagai pembimbing kedua dilingkungan sekolah atau bagi anak usia dini adalah pada jenjang pra sekolah. Oleh karena itu, konstruksi kemandirian bukan hanya terjadi dan diperhatikan dilingkungan keluarga atau rumah saja, tetapi ketika 

anak memasuki usia pra sekolah kemandirian menjadi suatu hal yang sangat penting untuk diperhatikan perkembangannya.

Realitas dilapangan dilihat dari hasil penelitian terdahulu menggunakan pendekatan eksperimen yang dilakukan oleh Mahyumi (2015) menunjukan bahwa masih kurang optimalnya kemandirian anak usia dini, dilihat dari pada saat kedatangan murid diantar sampai ke dalam kelas, masih ada anak yang belum mampu membuka/memakai sepatu sendiri, ketika berbaris masih ada yang belum mampu mengikuti aturan dalam berbaris, bahkan didalam proses pembelajaran di dalam kelas anak sering membiarkan mainan berserakan setelah selesai bermain. Penelitian yang dilakukan oleh Anisah (2017) pun menunjukan bahwa dari 22 orang anak hanya sekitar $35 \%$ (8 orang anak) saja yang mampu mengerjakan tugas yang diberikan guru dengan baik. Tugas-tugas tersebut antara lain : meletakkan tas dan tempat minum pada tempatnya, menyiapkan pekerjaan, makan dengan baik, serta kegiatan lain yang biasa dilakukan anak di dalam kelas. Sementara itu, sebagian besar anak belum mampu menyelesaikan tugas dengan baik, anak selalu meminta bantuan pada guru. Adapun penelitian tentang peninjauan kemandirian anak dilakukan oleh Dhamayanti dan Yuniarti (2006) yang menunjukan hasil bahwa pra sekolah full day school lebih menumbuhkan kemandirian anak dibandingkan dengan keluarga karena menurut hasil penelitian tersebut, keluarga lebih subjektif dalam menilai kemandirian anak mereka.

Menurut Dogde kemandirian anak usia dini dapat dilihat dari pembiasaan dan kemampuan anak dalam kemampuan fisik, percaya diri, bertanggungjawab, disiplin, pandai bergaul, mau berbagi, mengendalikan emosi (Dodge, 2008). Sejalan dengan pendapat Dodge menurut Brawer (dalam Havinghurts, 1993) bahwa "Kemandirian merupakan perilaku yang terdapat pada seseorang yang timbul karena dorongan dari dalam dirinya sendiri, bukan karena pengaruh orang lain. Brewer juga menyatakan bahwa kemandirian anak Taman Kanak-kanak indikatornya adalah pembiasaan yang terdiri dari kemampuan fisik, percaya diri, bertanggungjawab, disiplin, pandai bergaul, mau berbagi, mengendalikan emosi". Menurut Steinberg (1995) remaja yang memperoleh kemandirian adalah remaja yang memiliki kemampuan untuk mengatur diri sendiri secara bertanggung jawab, meskipun tidak ada pengawasan dari orang tua ataupun guru. Kondisi inilah yang menyebabkan remaja memiliki peran baru dan mengambil tanggung jawab baru, sehingga hal ini akan menempatkan remaja untuk menjadi tidak tergantung pada orang tua untuk memperoleh kemandirian secara penuh sehingga masalah kemandirian secara spesifik menuntut suatu kesiapan individu baik secara fisik maupun emosional untuk mengatur, mengurus, dan melakukan aktivitas atas tanggung jawabnya sendiri tanpa banyak tergantung pada orang lain. Sedangkan pada anak usia dini menurut Susanto (2016) adalah kemampuan seorang anak untuk menentukn pilihannya yang ia anggap benar, selain itu anak mampu bertanggung jawab dan menerima konsekuensi atas pilihannya itu. Tentunya Susanto (2016) menegaskan bahwa kemandirian bagi anak sifatnya masih pada taraf sederhana, sesuai dengan tingkat perkembangannya. Menurut Morrison (2012) kemandirian itu sendiri berarti kemampuan anak untuk mengerjakan tugas sendiri, menjaga diri sendiri, dan memulai proyek tanpa harus selalu diberitahu apa yang harus dilakukan.

Faktor yang mempengaruhi kemandirian anak diantaranya adalah orang tua, pendidik disekolah juga lingkungan yang dihadapi anak. Menurut 

Medhus (2005) Orang tua banyak yang tidak menyadari potensi yang dimiliki anak sehingga menjadikan pemikiran orang tua yang ingin melihat anaknya sukses membuat para orang tua memberikan peran ikut campur dalam pengambilan keputusan, seharusnya anak dibiarkan dan dipercaya untuk memilih pilihannya dengan penjelasan konsekuensi yang akan diterima anak. Sementara itu menurut Susanto (2016) Kemandirain sangat dipengaruhi oleh kepercayan diri, yang mana jika anak merasa aman dan sudah percaya diri dia akan lebih maua melakukan penjelajahan sendiri, lebih mampu mengelola stres dan banyak hal yang dapat anak capai.

$$
\text { Menurut Susanto }
$$

Pembelajaran anak usia dini harus dilakukan secara terencana, pendidik harus memerhatikan berbagai aspek perkembangan. Menurut Syaodih (2005), tujuan bimbingan adalah untuk membantu anak didik mengenal dirinya dan lingkungan terdekatnya sehingga dapat menyesuaikan diri dari melalui tahap peralihan dari kehidupan rumah menuju ke kehidupan sekolah dan masyarakat sekitar, oleh karena itu membentuk kemandirian di usia dini.

\section{METODE}

Desain penelitian yang digunakan dalam penelitian ini adalah menggunakan jenis penelitian studi kasus. Menurut Bungin (2014, hlm. 132) menyatakan bahwa studi kasus merupakan studi yang mendalam hanya pada satu orang atau peristiwa. Selain itu Sugiyono (2011, hlm. 14) menyatakan bahwa studi kasus merupakan salah satu jenis penelitian kualitatif, dimana peneliti melakukan eksplorasi secara mendalam terhadap program, kejadian, proses, aktivitas, terhadap satu atu lebih orang.

Alasan peneliti menggunakan pendekatan kualitatif dengan desain penelitian studi kasus, karena peneliti ingin meneliti secara mendalam tentang pandangan orang tua dan guru mengenai faktor dan kemunculan kemandirian pada anak usia dini secara lebih mendalam.

Partisipan dalam penelitian ini yaitu enam responden yang terdiri dari 3 guru kelas dan 3 orang tua siswa. Penelitian ini dilakukan selama kurang lebih delapan bulan mulai dari persiapan, tahap wawancara, observasi, dan analisis sampai pada pelaporan.

Penelitian ini memerlukan subjek penelitian atau narasumber untuk mendapatkan data atau informasi. Dalam penelitian ini, sumber data yang diperoleh menggunakan prosedur kuota yang dimana peneliti memutuskan saat merancang penelitian, berapa jumlah informan yang akan digunakan serta karakteristik informan yang dibutuhkan oleh peneliti (Bungin, 2014).

\section{HASIL DAN PEMBAHASAN}

Pandangan guru dan orang tua mengenai kemandirian anak usia dini ini merupakan hasil kajian peneliti terkait dengan apa yang guru dan orang tua pahami mengenai kemandirian anak usia dini dan upaya yang orang tua lakukan dalam membentuk kemandirianpada anak mereka guna mempersiapkan anak menjadi individu yang dapat berdiri sendiri dan melakukan apapun dengan mandiri.

Peneliti ingin memaparkan bahwasannya peran guru dan orang tua sangatlah berpengaruh dalam pembentukan kemandirianpada anak usia dini, sehingga peneliti ingin memberikan gambaran terkait pandangan guru dan orang tuamengenai kemandirian anak usia dini.

Bagian ini menguraikan temuantemuan dari hasil wawancara peneliti dilapangan dengan enam orang partisipan. Temuan dan pembahasan dari data yang sudah dikumpulkan kemudian dituliskan pada pengategorisasian tema dari hasil analisis. Temuan-temuan di analisis menggunakan teori dan hasil- 

hasil penemuan dilapangan. Terdapat tiga tema yang akan dibahas pada bab ini mengenai Kemandirian Anak Usia Dini di Taman Kanak-kanak menurut Pandangan Orang Tua dan Guru, yaitu: Gambaran kemandirian anak menurut pandangan orang tua dan guru, Faktor yang mempengaruhi kemandirian anak Kompleksitas orang tua dalam memandang gadget

\section{Gambaran kemandirian anak menurut pandangan orang tua dan guru}

Pada pembahasan ini, peneliti meyakini gambaran kemandirian anak juga dipengaruhi oleh karakteristik anak yang ada disusunan pertama yang akan peneliti bahas. Akah tetapi, pada kenyataan dilapangan saat wawancara, para orang tua dan guru terlebih dahulu mendeskripsikan mengenai definisi kemandirian itu sendiri sebelum pada karakteristik anak usia dini karena karakteristik usia dini terjabarkan saat mendeskripsikan definisi kemandirian anak itu sendiri.

Guru dan orang tua memahami bahwa karakteristik anak usia dini adalah meniru, oleh sebab itu apa yang dilakukan dan dikerjakan orang tua atau guru sangat erat kaitannya dengan apa yang akan dilakukan anak. Sejalan dengan pnelitian yang dilakukan oleh Khairi (2018) karakteristik lain yang dimiliki anak adalah suka meniru, dimana anak meniru apa yang seseorang dan sangat mengesankan bagi dirinyasehingga anak akan meniru dan melakukan sebagaimana yang ia lihat. Meskipun apa yang dia tersebut tidak bermanfaat bagi dirinya, dan bahkan anak-anak tidak mengerti apakah itu baik atau buruk. Yang diketahui anak adalah bahwa yang ia lihat tersebut sangat berkesan bagi dirinya sehingga ia berusaha untuk menirunya.

Orang tua memandang bahwa bentuk perlakuan terhadap adiknya pun merupakan bentuk kemandirian, dimana sang anak memilihkan baju untuk adiknya dan membantu ibunya. Bentuk kemandirian itu sendiri adalah perilaku yang menunjukan kemandirian anak.

Kebiasaan sehari-hari yang dilakukan sendiri oleh anak tanpa meminta bantuan apapun juga merupakan kemandirian. Maka dari itu menurut Montessori (2017) penguasaan kemandirian pertama kali menyentuh anak adalah pada saat anak lahir kedunia, oleh sebab itu setiap anak mengalami pertumbuhan dan perkembangan sebenarnya ia juga sedang membentuk kemandiriannya. Dalam penelitiannya Rahma, Utami dan Hapidin (2016) menjelaskan bahwa bentuk membantu orang tua dirumah itu termasuk pada kemandirian anak, dimana anak memiliki inisiatif sendiri membantu orang tua setelah orang tua membiasakana anaknya untuk dapat melakukan sesuatu hal sendiri. Oleh karena bentuk kemandirian anak pun dapat berupa pemberian bantuan pada orang lain khususnya ibu dirumah.

Ciri-ciri anak yang telah terbentuk kemandiriannya adalah dia yang dapat menyesuaikan diri dengan lingkungan baru tanpa harus didampingi oleh orang tuanya. Sejalan dengan Tim Pustaka Familia (2006) ciri kemandirian anak dimana anak tidak merasa khawatir bila terlibat masalah karena anak sudah mengerti dengan konsekuensi yang ada anak pun tidak selalu meminta bantuan karena anak memilki kontrol yang baik terhadap hidupnya.

\section{Faktor yang mempengaruhi kemandirian anak usia dini}

Berdasarkan penjelasan pada tema sebelumnya, yaitu gambaran kemandirian anak usia dini, peneliti mencoba untuk mencari tahu lebih dalam faktor-faktor yang mempengaruhi terbentuknya kemandirian anak usia dini dilihat dari pandangan orang tua dan guru. Dari hasil wawancara ditemukan empat inti utama yang dapat menjelaskan bagaimana 

pembentukan kemandirian anak usia dini dilingkungan rumah dan lingkungan sekolah. Inti utama yang peneliti temukan dari hasil wawancara adalah Strategi orang tua dalam membentuk kemandirian anak, Strategi sekolah untuk membentuk kemandirian anak, faktor pendorong kemandirian anak dan faktor penghambat kemandirian anak. Semua faktor ini akan dijelaskan lebih lanjut pada tema terakhir ini.

Menurut Setyowati (2005) menjelaskan bahwa pola komunikasi keluarga yang diterapkan akan menentukan pembentukan dan perkembangan emosi dan karaker anak. Komunikasi yang baik pun bukan hanya terjadi pada orang tua dan anak selaku pemberi strategi dan penerima strategi tetapi komunikasi antara ayah dan ibu pula sangat berpengaruh pada pembentukan kemandirian anak. Kekompakan antara ayah dan ibu dapat menjadi strategi yang baik untuk membentuk kemandirian anak.

Dalam menumbuhkan kemandirian anak dukungan sangat diperlukan karena itu dapat menumbuhkan rasa percaya diri anak sehingga anak dapat dengan percaya diri melakukan apa yang dia inginkan. Sabar pun merupakan salah satu strategi yang dikemukakan oleh para responden karakteristik egosentisme dimana anak masih punya sisi bahwa keinginnya yang harus diutamakan maka dalam pembentukan kemandiriannya strategi orang tua dalam pembentukan kemandirian adalah sabar. Sabar dapat diartikan sebagai suatu pemahaman orang tua terhadap karakteristik. Dalam wawancara salah satu responden yang merupakan seorang ayah mengemukakan bahwa sabar merupakan salah satu strategi pembentukan kemandirian anak.

Hal lain yang menjadi faktor yang mempengaruhi pembentukan kemandirian anak adalah strategi pembentukan kemandirian anak disekolah. Tidak dapat dipungkiri bahwa sekolah pun dapat menjadi strategi orang tua dalam membentuk kemandirian anak. Karena lingkungan sekolah adalah lingkungan yang baru untuk anak maka harus ada beberapa strategi dalam membentuk kemandirian anak. Sejalan dengan Syaodih (2005) bahwa bimbingan guru bertujuan untuk memabntu peserta didik agar dapat menyesuaikan diri melalui tahap peralihan dari kehidupan dirumah menuju kehidupan sekolah. Oleh karena itu strategi sekolah dalam pembentukan kemandirian sangat penting.

Pemberian dukungan berupa pujian dan reward merupakan sebuah strategi yang dianggap efektif bagi guru karena mengingat karakteristik anak tadi. Anak merasa didukung oleh kita akan merasa dihargai keberadaannya, dukungan ini dapat berpa verbal atau non verbal seperti pemberian reward berupa bintang atau apapun yang dapat menumbuhkan motivasi anak (Puspitasari, 2016). Selain itu temuan dilapangan menunjukan bahwa guru mempunyai strategi pembentukan kemandirian yang lain, agar anak tidak merasa terpaksa untuk melakukan suatu pembentukan seperti dengan metode bercerita, permaianan dan lagu. Itu semua hal yang dapat menarik perhatian anak dan dianggap dapat membentuk kemandirian anak tanpa anak sadari.

Dari hasil temuan salah satu orang tua memandang kedekatan ayah dengan anaknya dapat menjadi faktor pendorong kemandirian anak, itu dipicu pula dari ibu yang bekerja dari hasil wawancara dengan ibu Desi. Sejalan dengan hasil penelitian yang dilakukan oleh Geovany (2016) bahwa presentase kemandirian anak yang ibunya bekerja lebih tinggi dibandingkan ibu yang tidak bekerja.

Hal yang menjadi temuan yang menarik dari hasil wawancara peneliti dengan salah seorang ibu adalah bagaimana trauma dapat menjadi pendorong terbentuknya kemandirian 

anak. Dalam hal ini ibu Desi menceritakan bagaimana anaknya dapat memperlihatkan beberapa bentuk kemandirian setelah mengalami trauma.

Setelah penjelasan mengenai beberapa faktor pendorong, sekarang beralih ke faktor penghambat kemandirian anak. Pasya (2007) mengemukakan bahwa perilaku orang tua sangat berpengaruh terhadap munculnya problematika kejiwaan anak yang dapat menimbulkan rasa takut dan tidak percaya diri, sehingga dapat menimbulkan ketidakmandirian.

Terdapat beberapa faktor penghambat kemandirian diantanya adalah perbedaan pola asuh orang tua dan nenek, dimana ibu Desi mengungkapkan bahwa nenek kadang selalu memanjakan dan membela apa yang orang tua larang itu menjadi hambatan karna akan membuat anak bingung. Sejalan dengan yang dikemukakan dalam penelitian Latifah, Krisnatuti dan Puspitawati (2010) bahwa nenek cenderung memiliki pola asuh yang permisif sehingga membuat pembentukan kemandirian anak terhambat. Selain dari perbedaan pola asuh orang tua dan nenek yang menjadi temuan menarik adalah gadget juga berperan sebagai faktor penghambat kemandirian anak. Jika televisi dapat menjadi media orang tua untuk memebentuk kemandirian anak, lain halnya dengan gadget ketiga partisipan yang merupakan orang tua setuju bahwa gadget adalah faktor penghambat kemandirian anak.

\section{Kompleksitas orang tua dalam memandang gadget}

Dalam era globalisasi ini tidak dapat dipungkiri bahwa gadget merupakan suatu hal yang tidak dapat lepas dari kegiatan manusia. Hal yang menjadi menarik dalam temuan kali ini adalah dua dari orang tua memandang dan menggunakan gadget sebagai media untuk membentuk kemandirian anak gadget yang di gunakan adalah televisi.
Televisi dianggap dapat membuat anak membentuk kemandirian anak yaitu makan sendiri.

Dua dari tiga orang tua memanfaatkan televisi yang merupakan gadget sebagai media pembentuk kemandirian anak, walaupun kemandirian yang dibentuk dari contoh yang orang tua berikan hanya ketika anak makan saja. Meski begitu itu dapat membuka pandangan bahwa tidak semua gadget berdampak negatif pada anak, gadget berbahaya atau tidaknya tergantung dari bagaimana orang tua dapat menyikapi penggunaannya dengan bijak. Seperti yang dikemukakan oleh Palar, Onibala dan Oroh (2018) melalui gadget orang tua akan lebih efektif dalam memberi pembelajaran pada anak, akan tetapi gadget akan berpengaruh negatif apabila orang tua memberikan penguasaan penuh ketika anak menggunakan gadget. Maka dari itulah orang tua harus dapat memanfaatkan gadget sebaik mungkin untuk pembentukan khusunya kemandirian anak tetapi juga tidak melepaskan anak begitu saja dengan gadgetnya pengawasan dan pembatasan harus terus dilakukan mengingat gadget pun memiliki efek negatif.

\section{SIMPULAN}

Melalui hasil penelitian ini dapat diungkapkan bahwa kemandirian anak usia dini menurut pandangan guru dan orang tua menunjukan tiga hal yaitu gambaran guru dan orang tua mendeskripsikan kemandirian anak, faktor yang mempengaruhi terbentuknya kemandirian anakdan kompleksitas orang tua dalam memandang gadget terhadap kemandirian anak. Pada hasil penelitian ini ditemukan guru dan orang tua memandang karakteristik anak dapat dijadikan patokan untuk merancnag strategi pembentukan kemandirian anak. Dimana anak akan memunculkan bentukbentuk kemandirian seperti melepas dan memakai sepatu sendiri, memilih baju 

sendiri, dapat cuci tangan sendiri, serta anak yang dianggap guru dan orang tua mandiri adalah anak yang dapat membantu orang lain pula. Guru dan orang tua pun setuju bahwa anak yang mandiri itu akan mengeluarkan ciri seperti sudah terbentuknya kepercayaan diri, cenderung disiplin, mempunyai inisiatif dalam melakukan berbagai hal dan teliti dalam melakukan sesuatu kegiatan. Dalam temuan penelitian juga ditemukan ciri anak yang kemandiriannya telah muncul seperti tidak dapat dipengaruhi oleh orang lain tetapi anak cenderung dapat mempengaruhi orang lain dan dapat bertanggung jawab pada tugas yang telah diberikan.

Selain memperlihatkan gambaran tentang kemandirian anak menurut pandangan guru dan orang tua hasil penelitian ini mennunjukan bahwa ada bebrapa faktor yang mempengaruhi terbentuknya kemandirian anak. Orang tua mempunyai strategi yang beragam dalam membentuk kemandirian anak salah satunya adalah pelibatan anak dalam kegiatan sehari-hari (partical life), peran siblings, peran lomba dan peran piknik serta penggunaan media seperti televisi merupakan strategi orang tua. Selain orang tua sekolah pun mempunyai strategi yang beragam untuk membentuk kemandirian anak yang membuat anak tidak merasakan sedang dibentuk kemandiriannya seperti pembiasaan dengan pemberian dukungan pada anak juga penyesuaian dan penyediaan sarana dan prasarana yang menunjang pembentukan kemandirian anak. Selain itu ada beberapa faktor yang dapat menjadi penghambat dan pendorong kemandirian anak tiga responden setuju bahwa salah satu faktor penghambat terbentuknya kemandirian anak adalah nenek yang terlalu memanjakan cucunya, kakak yang tidak mandiri pun dapat menjadi penghambat kemandirian anak karena karakteristik anak itu meniru sehingga lingkungan keluarga dan sekolah itu berpengaruh pada pembentukan kemandirian anak. Selain faktor penghambat ditemukan pula faktor pendorong terbentuknya kemandirian ke enam partisipan setuju bahwa sinkronisasi aturan baik dirumah dan disekolah, ayah dan ibu, orang tua dan guru itu sangat menjadi pendorong terbentuknya kemandirian.

\section{DAFTAR RUJUKAN}

Anisah. (2017). Penerapan Metode Pemberian Tugas untuk Meningkatkan Kemandirian Anak Usia 5-6 Tahun di TK Satu Atap SDN 003 Sihepeng Tahun Ajaran 2016/2017. Jurnal Guru Kita (JGK). Vol 2 (1). p-ISSN :2548883X.

Bungin, H. M. (2014). Penelitian Kualitatif. Jakarta: Prenada Media Group.

Desmita. (2011). Psikologi Perkembangan Peserta Didik. Bandung: PT. Remaja Rosda Karya.

Geovany, R. (2016). Perbedaan Kemandirian Anak Usia Dini ditinjau dari Ibu Bekerja Dan Ibu Tidak Bekerja. Jurnal Psikoborneo, 4(4). doi: ejournal.psikologi.fisipunmul.ac.i d

Khairi, H. (2018). Karakterisitik Perkembangan Anak Usia Dini dari 0-6 Tahun. Jurnal Warna, Vol.2, No.2. e-ISSN: 2550-0058

Latifah, EW, Krisnatuti \& Puspitawati, (2016). Pengaruh Pengasuhan Ibu dan Nenek terhadap Perkembangan Kemandirian dan Kognitif Anak Usia Prasekolah. Jurnal Ilmu Keluarga dan Konsumen. Vol 9, No 1. doi: https://doi.org/10.24156/jikk.2016 .9 .1 .21 

Montessori, M. (2017). The Absorbent Mind. Yogyakarta: Pustaka Pelajar.

Medhus, E. (2005). Raising Independent Children. Jakarta: PT Bhuana Ilmu Populer.

Morrison, G.S. (2012). Dasar-dasar Pendidikan Anak Usia Dini. Jakarta: Indeks.

Pasya, H. S. (2007). Bimbingan Mendidik Anak Sejak Kecil Hingga Dewasa. Bandung: Dinamika Pustaka.

Puspitasari, R. (2016). Pengaruh Pemberian Hadiah (Reward) terhadap Kemandirian Belajar Anak di TK Tunas Muda Karas Kabupaten Magetan Tahun Ajaran 2015/2016. ISBN: 978979-3456-52-2. doi: http://jurnal.fkip.uns.ac.id/index.p hp/pip/article/view/7503/5360.

Rahma, S, Utami \& Hapidin. (2016). Kemandirian Anak Usia 5-6 Tahun di Komunitas Lingkungan Pemulung. Jurnal Ilmiah Visi PPTK PAUDNI. Vol. 11, No. 01. doi: https://dx.doi.org/10.21009/JIV.1 101.2.
Setyowati, Y. (2005). Pola Komunikasi Keluarga dan Perkembangan Emosi Anak (Studi Kasus Penerapan Pola Komunikasi Keluarga dan Pengaruhnya terhadap Perkembangan Emosi Anak pada Keluarga Jawa). Jurnal Ilmu Komunikasi, Vol. 2, No. $1 . \quad$ doi: https://doi.org/10.24002/jik.v2i1.2 $\underline{53 .}$

Steinberg, L. (1995). Adolsence. Sanfransisco: McGraw-Hill Inc.

Sugiyono. (2011). Metode Penelitian dan Pengembangan. Bandung: Alfabeta.

Susanto, A. (2016). Pendidikan Anak Usia Dini. Jakarta: Bumi Aksara.

Syaodih, E. (2005) Bimbingan di Taman Kanak-Kanak. Jakarta: Depdiknas

Tim Pustaka Familia. (2006). Membuat Prioritas Melatih Anak Mandiri. Yogyakarta: Kanisius.

Undang-Undang No. 20 Tahun 2003 Tentang Sistem Pendidikan Nasional.

Yamin, M. (2013). Panduan Pendidikan Anak Usia Dini. Ciputat: Gunung Persada Press Group. 